ReVISTA de BIOLOGía TROPICAL

\title{
Questioning the environmental stress hypothesis for gall diversity of restinga vegetation on dunes
}

\author{
Ígor A. Arriola ${ }^{1}$, João Carlos F. Melo Jr. ${ }^{1}$ \& Rosy Mary S. Isaias ${ }^{2 *}$
}

1. Laboratório de Anatomia e Ecologia Vegetal, Departamento de Ciências Biológicas, Universidade da Região de Joinville, Rua Paulo Maschitzki 10, CEP 89219-710, Joinville, SC, Brazil; arriolaigor@gmail.com, jcmelo_wood@hotmail.com

2. ICB - Departamento de Botânica, Universidade Federal de Minas Gerais, Av. Antonio Carlos, 6627, Pampulha, CEP 31270-901, Belo Horizonte, MG, Brazil; rosy@icb.ufmg.br

Received 27-I-2015. Corrected 05-VII-2015. Accepted 03-VIII-2015.

\begin{abstract}
The Atlantic Coast Restinga is a mosaic of plant communities with a distinct floristic and phytophysiognomy, exposed to luminous, thermal, and saline stresses. Plants of the restinga must have special features commonly associated to xeric environments, and are expected to host a high diversity of galling herbivores. We studied gall morphotypes, and recorded the diversity of galls on plants growing in sand dunes in a remnant area of restinga (Acaraí State Park) in São Francisco do Sul, Santa Catarina State, Brazil. The sampling was done in four plots $(250 \times 5 \mathrm{~m})$, constituting a total area of $5000 \mathrm{~m}^{2}$, during April, May and June. Plant branches $(\mathrm{n} \geq 5)$ with galls were sampled, identified, and the galls were photographed. The galls were classified into eight morphotypes, associated to eight host plants constituting 15 host plants - galling herbivores systems. The identification of the gall - inducers was based on literature, and on the species-specific feature of this kind of host plant-gall inducers interaction. There was a predominance of leaf galls, green in color. The most common morphotypes were the globoid, lenticular, conical, rosette, marginal, and fusiform galls, similarly to the inventories performed on other Brazilian biomes. Despite the environmental stresses, the xeric features of the dunes of the ASP, and the high local plant diversity, the diversity of galling herbivores were low. Varronia curassavica (Boraginaceae), Smilax campestris (Smilacaceae), and Guapira opposita (Nyctaginaceae) were superhosts of galling herbivores in the dunes, with about $70 \%$ of the total associated parasites. The environmental effect seems to be neutral, either for the host plants or for the generation of gall morphotypes. Alternatively, the scarce nutritional resources could be restrictive for the establishment of the galling herbivores inside plant tissues. Rev. Biol. Trop. 63 (4): 959-970. Epub 2015 December 01.
\end{abstract}

Key words: dunes, environmental stress, insect-plant interaction, restingas, super-hosts.

The Atlantic Coast Restinga is a mosaic of plant communities, a component of the Atlantic Forest, with a distinct floristic and phytophysiognomy located on plains of Quaternary origin (Scarano, 2002). The major coastal portion of the restinga has pioneer vegetation on sand banks, and is highly influenced by the topography, salinity, water shortages, incidence of winds and acidic nutrient-poor soils (Bigarella, 2001; Boeger \& Gluzezak, 2006). The halophyte plants, called psammophiles, play a key role in the stabilization of sand and natural drainage of this environment (Cordazzo, Paiva, \& Seeliger, 2006).

A greater diversity of gall-inducing insects is expected to occur in hygrothermally stressed environments (Fernandes \& Price, 1988), such as that of the dunes of the restinga. Galls are plant structures that protect and nurture the larvae of the gall - inducing insect (Abrahamson \& Weis, 1987; Fernandes \& Price, 1991; Fernandes \& Price, 1992; Raman, Schaefer, \& Withers, 2005; Shorthouse, Wool, \& Raman, 2005) which consist of a wide and 
taxonomically unknown fauna of galling herbivores in species-specific interactions, resulting in closely related morphotypes (Isaias, Carneiro, Oliveira, \& Santos, 2013; Isaias, Carneiro, Santos, \& Oliveira, 2014). These morphotypes are representative of the diversity of the inducing insects (Floate, Fernandes, \& Wilson, 1996; Carneiro et al., 2009), which should also be associated with a diversity of insects at other tropic levels (Dreger-Jauffret \& Shorthouse, 1992; Stone \& Schonrogge, 2003). Galling insects-host plants relationships are generally species-specific, nevertheless, some taxa are capable of hosting three or more gall morphotypes, which indicated their capability of reacting to the stimuli of more than one inducer. These host plants are named "superhosts", and contribute to the increasing of the diversity of gall - inducing insects in a given area (Araújo, Scareli-Santos, Guilherme, \& Cuevas-Reyes, 2013).

There is an estimated $21000-211000$ gallinducing species of insects (Espirito-Santo \& Fernandes, 2007), in addition to an extensive associated guild of parasitoids, inquilines, predators and successors (Maia, 2001). The diversity of galls in the restingas has been mainly inventoried in Rio de Janeiro, São Paulo, and Espírito Santo states (Maia, 2001; Oliveira \& Maia, 2005; Maia, Magenta, \& Martins, 2008; Bregonci, Polycarpo, \& Maia, 2010; Maia, 2013). In contrast, the literature on galls and their inducers from the coastal regions of Southern Brazil is restricted to a single inventory in Rio Grande do Sul state (Mendonça Jr., Piccardi, Janhke, \& Dalbem, 2010).

As far as we are aware, the current inventory represents the first systematic effort to sample galls on the restingas of Santa Catarina state, focusing specifically on the vegetation of the dunes. As Formiga, Silveira, Fernandes and Isaias (2014) proposed, we use the widely accepted concept of gall morphotypes, for it has been widely used in inventories of gall diversity and richness in the Neotropics. Also, each pair of host plant-gall inducer is referred to as a morphospecies, similar to PortugalSantana and Isaias (2014).
This study presents the inventory of the galls, and their morphology, focusing on future physiological and ecological researches on the plant-insect interactions at the dunes of the Acaraí State Park (ASP) in São Francisco do Sul municipality. The gall morphotypes are herein used to estimate the richness and diversity of galling herbivores, as proposed by Carneiro et al. (2009). Based on Fernandes and Price (1988), these diversity and richness should be higher in xeric environments, as the dunes of the ASP. Our objective is to perform the inventory of the gall morphotypes on the dunes of the ASP, and discuss the data together with the patterns of distribution and adaptive convergences of the galls to the peculiar environment on host species and morphotypes basis.

\section{MATERIAL AND METHODS}

The study area comprises a remnant area of restinga located in the municipality of São Francisco do Sul, in the coastal plain of Santa Catarina state, Brazil (48 $33^{\prime} \mathrm{W}-2^{\circ} 17^{\prime} \mathrm{S}$; Fig. 1). As an area of high priority for biodiversity conservation, it has been recently transformed into a Conservation Unit, the Acaraí State Park (ASP). With a total area of 6667 ha, the ASP is characterized by the presence of dunes (Fig. 2), restinga vegetation and lowland forests, other less repetitive formations also appear, as submontane forests, wetlands and mangroves (Fatma, 2008). The flora of the ASP is constituted of 319 species, belonging to 215 genera and 82 plant families. The most representative families in number of species are the Asteraceae (35), Fabaceae (30), Myrtaceae (20), Rubiaceae (18) and Poaceae (13) (Melo Jr., 2015). The local climate is Cfa of Köppen (subtropical climate, with hot summer), influenced by maritime humidity, with an average annual temperature of $20.3{ }^{\circ} \mathrm{C}$, and an average rainfall of $1874 \mathrm{~mm} /$ year (Knie ed., 2002). The soil is classified as quartzarenic neosoil (Melo Jr., 2015). The sampling was done in the herbaceous vegetation of the dunes on April $10^{\text {th }}$, May $29^{\text {th }}$, and June $11^{\text {th }}$ and $30^{\text {th }}, 2014$. The 


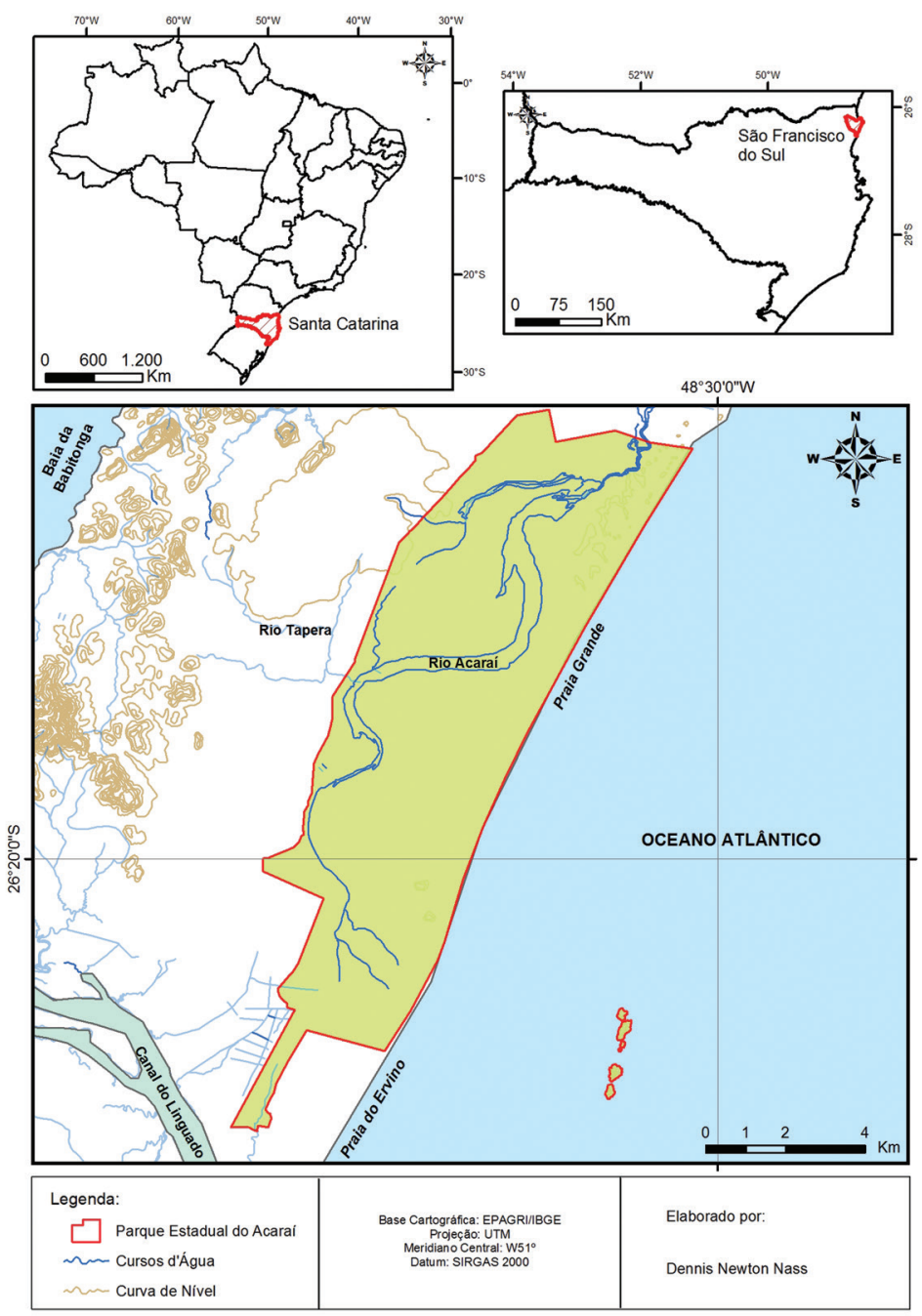

Fig. 1. Localization of Acaraí State Park (São Francisco do Sul, Brazil). Adapted from Melo Jr. 2015.

total sampling area measured $5000 \mathrm{~m}^{2}$, divided in four plots of $1250 \mathrm{~m}^{2}(250 \times 5 \mathrm{~m})$, and the insect galls were investigated during six hours in each plot, in a total of 24 hours.

All plants within the sampling area were inspected for the occurrence of galls. Plant branches $(n \geq 5)$ with galls were collected, and stored in labeled plastic bags. The host plants were identified to the lowest possible taxonomic level using the usual techniques for floristic studies (Fidalgo \& Bonoini, 1989). Plant material was also compared with the material in MBM Herbarium and with literature.
For confirmation of species names and their respective authors, the List of Species of Brazilian Flora (2014) was used. The vouchers were deposited in the Herbarium of the Universidade de Joinville (JOI). The identification of the galling insects was based on the revision of galls from the Southeastern Brazil (Maia, 2013). The gall morphotypes were classified according to Isaias et al. (2013), and photographed under a desk magnifier (model Toyo TL1020, 5 times magnifying lenses), with the aid of a digital camera, model Samsung ES68. 


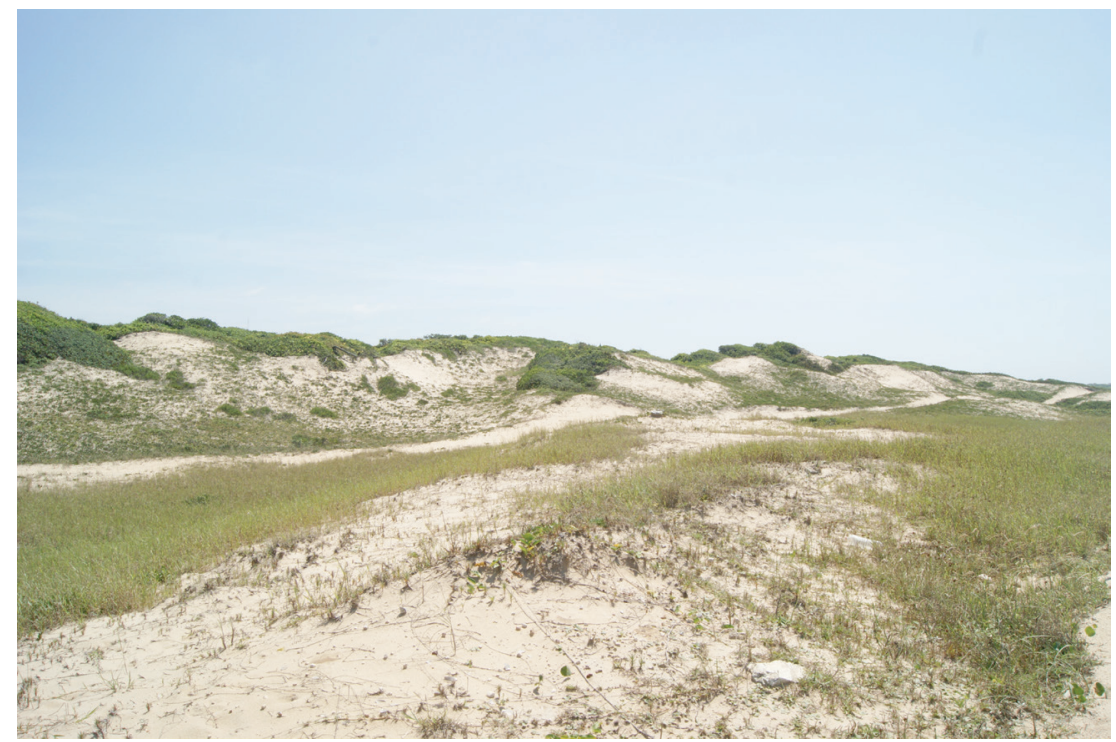

Fig. 2. Herbaceous vegetation on the dunes of Acaraí State Park (São Francisco do Sul, Brazil). Credits: João Carlos F. Melo Jr. (Personal archive).

\section{RESULTS}

The current inventory recorded 15 gall morphospecies on eight plant species, belonging to eight botanical families (Table 1; Fig. 3A, Fig. 3B, Fig. 3C, Fig. 3D, Fig. 3E, Fig. 3F, Fig. 3G, Fig. 3H, Fig. 3I, Fig. 3J, Fig. 3K, Fig. 3L, Fig. 3M, Fig. 3N, Fig. 3O, Fig. 3P and Fig. 3Q). These morphospecies were classified into six distinct morphotypes including simple isolated symmetric, globoid, lenticular, conical, rosette, marginal, and fusiform galls, and a ninth type, asymmetric, formed by the coalescence of galls. This last morphotype was exclusive of Guapira opposita and Smilax campestris, and was the most common gall morphotype, with $26.6 \%$ of occurrence, followed by the globoid and the lenticular (20\%), and the fusiform galls $(13.3 \%)$. The less frequent was the rosette, the marginal intumescence and the conical gall morphotypes (6.7\%, each).

The marginal intumescence gall in Scaevola plumieri Blume (Goodeniaceae) differed from a leaf rolling due to its succulence. Dalbergia ecastaphyllum L. (Taub.) (Fabaceae) had a minute lenticular gall. Also, some dry leaves of Smilax campestris Griseb. (Smilacaceae) were observed on the ground with opened galls on midrib veins. Most of the morphotypes occurred on leaves $(53.4 \%)$, with others on stems $(26.6 \%)$, petioles $(13.3 \%)$, and buds $(6.7 \%)$. The galls varied in color, with predominance of the green galls (46.6\%), followed by the brown and yellow (20\%), and the black and pink galls $(6.7 \%)$.

The host species diagnosed as superhosts of galling herbivores were Varronia curassavica Jacq. (Boraginaceae), Smilax campestris Griseb. (Smilacaceae) and Guapira opposita (Vell.) Reitz (Nyctaginaceae), with three or four gall morphotypes, each.

\section{DISCUSSION}

This is the first inventory of arthropod galls from the Acaraí State Park (ASP). It is also the first one whose sampling efforts were concentrated on the vegetation of dunes. The dunes are stressful environments, which constrains plant colonization (Cordazzo et al., 2006). Nevertheless, the botanical diversity of the dunes of ASP is notorious, with 77 plant species, 66 genera, distributed in 33 plant 


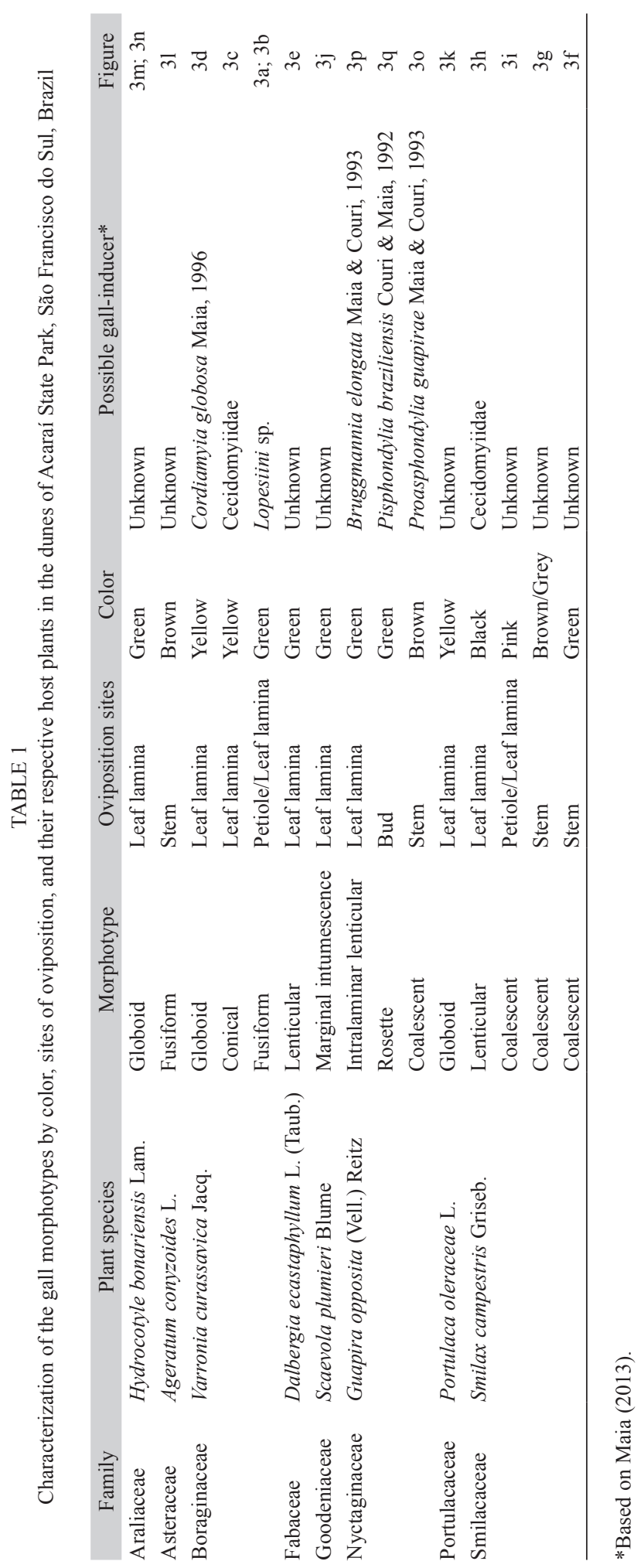



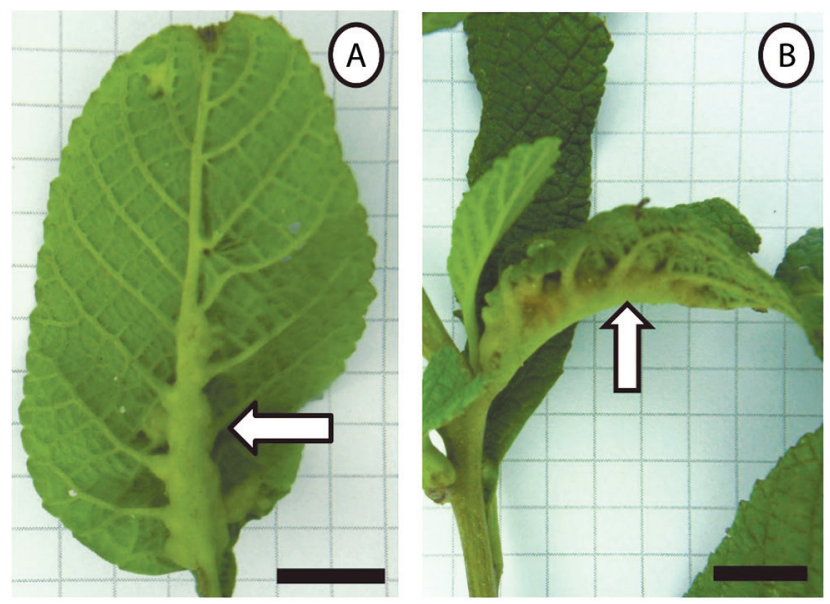

(B)

()
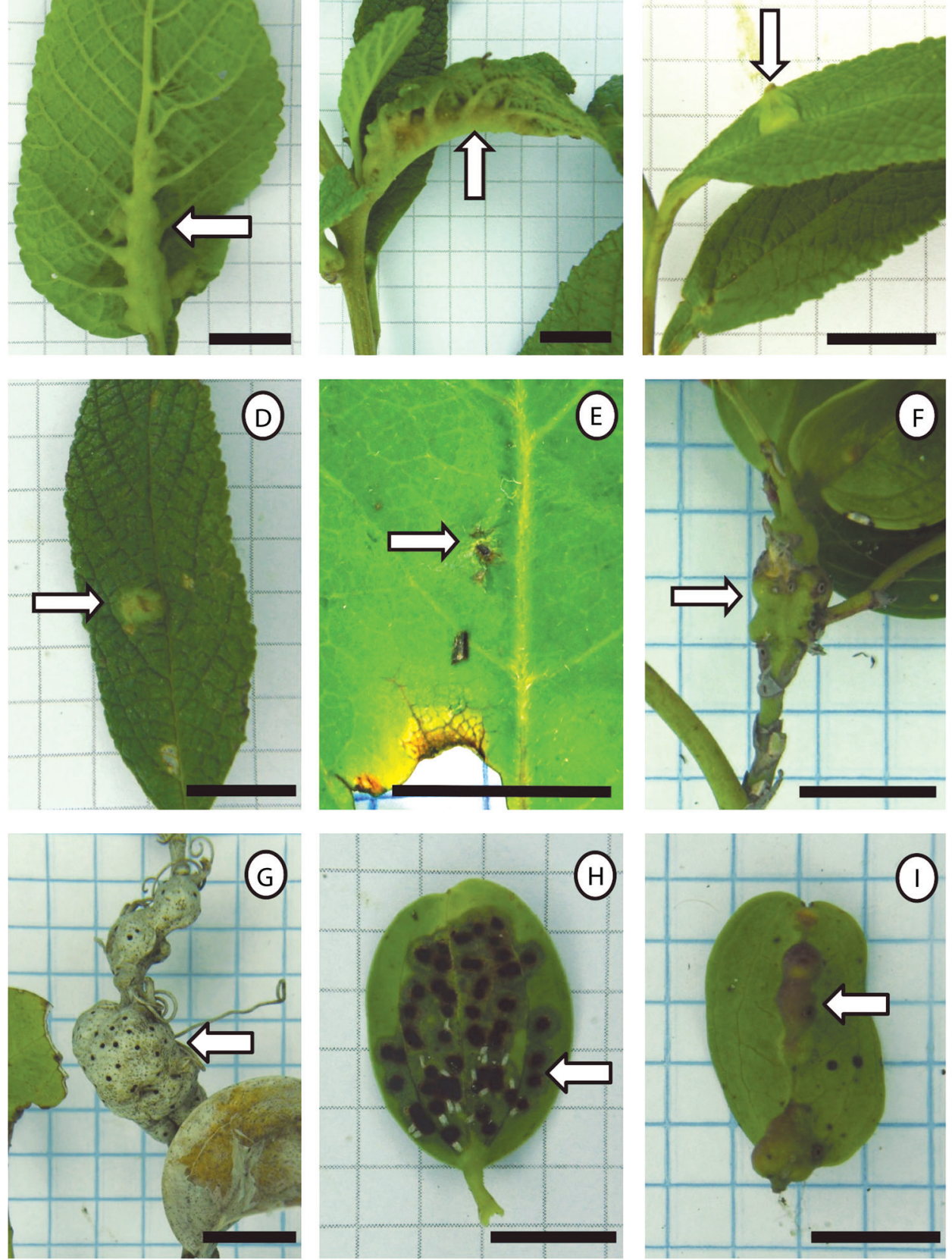

Fig. 3 (A-I). Galls of the dunes of Acaraí State Park (São Francisco do Sul, Brazil). Galls indicated by arrows. Scale bar = $1 \mathrm{~cm}$. A-D) Galls on Varronia curassavica (Boraginaceae). (A-B) Fusiform galls on the petiole and mid vein. (C) Conical gall. (D) Globose leaf gall. E) Lenticular open galls on Dalbergia ecastaphyllum (Fabaceae). F-I) Galls on Smilax campestris (Smilacaceae). F-G) Coalescent stem gall. H) Black lenticular gall with larvae on the opening of the scape channel. I) Pinkish coalescent leaf gall. 

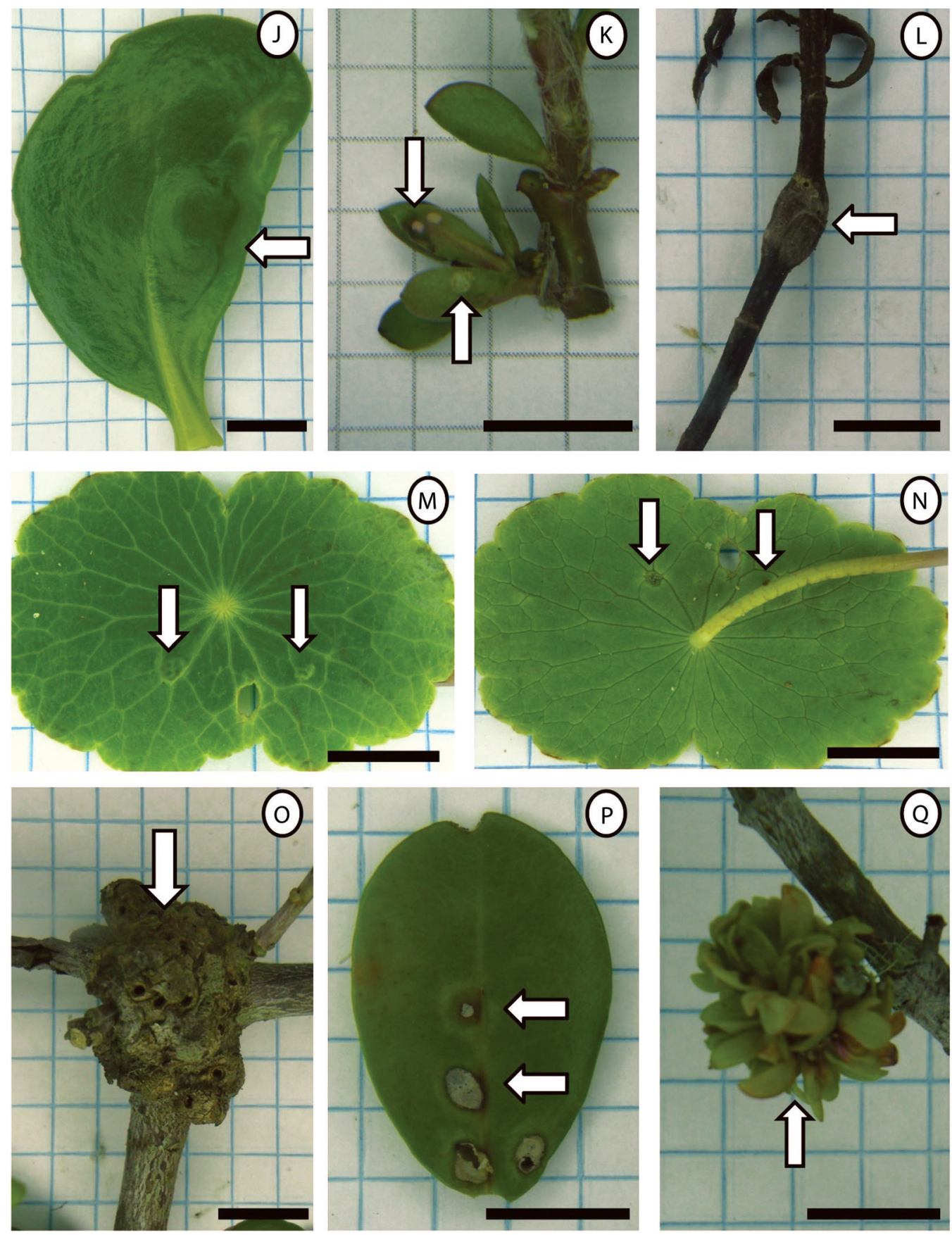

Fig. 3 (J-Q). Galls of the dunes of the Acaraí State Park (São Francisco do Sul, Brazil). Galls indicated by arrows. Scale bar $=1 \mathrm{~cm}$. J) Marginal leaf intumescence on Scaevola plumieri (Goodeniaceae). K) Globoid leaf gall on Portulaca oleraceae (Portulacaceae). L) Fusiform stem gall on Ageratum conyzoides (Asteraceae). M-N) Globoid galls. View from the adaxial (M) and the abaxial surface (N) on Hydrocotyle bonariensis (Apiaceae). O-Q) Galls on Guapira opposita (Nyctaginaceae). (O) Coalescent stem gall. (P) Intralaminar lenticular gall. (Q) Rosette gall. 
families (Melo Jr., 2015). The low number of interactions inventoried in the dunes (15 morphotypes in 8 plant species) cannot be related either to the low diversity of potential host plants, as proposed by Araújo (2011), or by the water stress, as predicted by Fernandes and Price (1992) for an increment on the diversity of galling herbivores on xeric habitats.

Considering the diversity of morphospecies as indicative of the insects's diversity (Floate et al., 1996; Carneiro et al., 2009), the highest the plant diversity, the highest should the galling herbivores distribution be, as proposed by Mendonça Jr. (2007). This author reported the Asteraceae and Myrtaceae as the host plant families with the highest diversity of galls in the restingas of Rio Grande do Sul. Unexpectedly, even though at the herbaceous vegetation of the restinga of the ASP, the Asteraceae was the most diverse plant family, with 13 of the 77 described species (Melo Jr., 2015), only one species of Asteraceae hosted galls at the ASP.

The presence of important superhosts, such as the G. opposita, V. curassavica and Smilax campestris influenced on the diversity of galling herbivores in the ASP, for these plants hosted almost $70 \%$ of the sampled morphotypes. Guapira opposita is a superhost of galling herbivores, which had already appeared in inventories of the restingas in the Southeastern region of Brazil, with up to ten different morphotypes (Maia, 2001; Maia et al., 2008; Maia \& Oliveira, 2010; Maia, 2013). These plant species hosts a galling Diptera: Cecidomyiidae, one of the most specialized group of galling herbivores (Maia et al., 2008; Maia, 2013). This plant species is also an important structuring species of the post-dune formations (shrub restinga), occurring less frequently in the herbaceous dunes (Melo Jr., 2015). In the dunes of the ASP, G. opposita hosts three gall morphotypes, corroborating its superhost feature. Current results reinforce the argument that the diversity of galls is related to the presence of superhosts in a given area (Mendonça Jr., 2007). In the dune vegetation, the superhost plants constitute just $4 \%$ of the vegetation, with inconspicuous phytosociological status (Melo Jr., 2015). The richness of the galling herbivores in the dunes seems to be closely related to the presence of the superhosts, and less to the environmental stresses. Anyhow, local diversity is in accordance to the expected for Neotropical systems (Araújo et al., 2013), with leaves being the preferential site of oviposition, for instance.

In the dunes of ASP, the preferential sites of oviposition is corroborated, with leaves hosting $66.7 \%$ of the recorded morphotypes, both in the petioles and in the leaf lamina. As the sites of the highest photosynthetic rates (Evert, 2013), the leaves have an optimum source of nutrients. Among the leaf gall morphotypes, the lenticular and the globoid are the most abundant. The globoid is, indeed, one of the most common gall morphotype in Brazilian flora, quoting for about $27 \%$ of the total galls listed by Isaias et al. (2014). Nevertheless, the lenticular morphotype quotes for about $2 \%$ of the galls recorded in the inventories checked by Isaias et al. (2013; 2014). In the ASP, together with the marginal intumescence and the conical morphotypes, the lenticular and globoid galls depict for the high morphogenetic potential of the host plants to respond to distinct galling stimuli. This capacity is neither linked to the host plant species nor to the environmental stresses; for these four geometrical final shapes also common on other host species were inventoried in other Brazilian biomes (i.e. Isaias et al., 2013).

The stem galls have a less variety of shapes, which demonstrated the less plastic potential of this host organ (Formiga et al., 2014) to alter its morphogenesis under external stimuli, such as that of the galling herbivores. The fusiform morphotype develops along the longest axis of the host stems with the increment in volume attributed to cell hypertrophy and tissue hyperplasia, as described by Ferreira and Isaias (2013) for stem galls on Marcetia taxifolia (Melastomataceae). The coalescent galls constitute more than $25 \%$ of the total gall morphotypes of the ASP. This relative high percentage of occurrence is a peculiarity of the 
galls on the vegetation of the ASP as well as in the checklist of Brazilian gall morphotypes (Isaias et al., 2013). The oviposition in near sites leading to the fusion of plant tissues does not appear as a main strategy of galling herbivores. Also, this gall shape had been referred as amorphous galls, and its coalescent nature was firstly reported by Isaias et al. (2013) for less than $0.5 \%$ of galls documented in the inventories. Alternatively, such confronting data may be result of underestimating field sampling or lack of standardization of nomenclature (i.e. Isaias et al., 2014).

The midrib gall on Smilax campestris seems to affect the stomatal conductance on its host plants, for dry leaves with galls were observed on the ground. The leaf falling may be consequence of a wound to the major vascular bundles, which should prejudice the hydraulic conductivity, affecting the stomatal conductance, resulting in precocious death of the leaves. This supposition is based on Sack, Dietrich, Streeter, Sánchez-Gómez and Holbrook (2008), who reported the loss of photosynthetic productivity, chlorophyll $a$ and $b$ contents, and stomatal conductance after the damage to the main vascular bundle. Also, galled portions of live branches, still attached to the host plants, had senescence features. When compared to similar stem galls on the same host plant, the galls had a higher proportion of survivorship with no indicatives of early senescence. In most of the host plants-galling herbivores systems, the life cycles are not synchronous, with the host leaves, living longer after gall eclosion, as reported for Psidium myrtoides-Nothotrioza myrtoidis (Carneiro, Oliveira, \& Isaias, 2014), for instance. However, some cases of synchrony should also occur as reported for Rollinia laurifolia-Pseudotectococcus rolliniae (Gonçalves, Isaias, Vale, \& Fernandes, 2005; Gonçalves, Moreira, \& Isaias, 2009), for Pseudobombax gradiflorumEriogalococcus isaias (Magalhães, Oliveira, \& Isaias, 2014). In cases of the host stems, when the galls do not affect the apical meristem, shoot axis may keep developing after gall senescence.
Taking for granted that the morphological aspects of the galls together with their speciesspecific association with their host plants are indicative of the taxonomical uniqueness of each gall morphotype, the inventory of galls of the ASP indicated that the presence of superhost plants is the most important factor affecting the relative richness of galling herbivores in the dunes, similarly to the observation for neotropical savannas (Araújo et al., 2013). The predominance of the globoid and fusiform galls is similar to the inventories in other Brazilian ecosystems, such as the restingas (Maia \& Oliveira, 2010; Maia \& Souza, 2013; Rodrigues, Maia, \& Couri, 2014), the Cerrado strictu sensu, and the rupestrian fields (Maia \& Fernandes, 2004; Carneiro et al., 2009; Malves \& Frieiro-Costa, 2012), the Amazon forest (Maia, 2011), the rain forest (Santos, Almeida-Cortez, \& Fernandes, 2011a; Santos, Almeida-Cortez, \& Fernandes, 2012), and the caatinga (Santos, Almeida-Cortez, \& Fernandes, 2011b), which demonstrates an adaptive convergence induced by the galling herbivores over the morphogenetic potential of distinct host plants. This first inventory on the vegetation of dunes indicates the neutral influence of this environment either on host species or generated morphotypes basis. An alternative interpretation deals with a convergent ecological strategy of the host plants in the peculiar environment of the dunes. The lack of nutritional resources for the plants should be restrictive for the galling herbivores to establish in plant tissues.

\section{ACKNOWLEDGMENTS}

The authors thank Universidade da Região de Joinville, Capes, CNPq, and FAPEMIG for financial support.

\section{RESUMEN}

Cuestionando la hipótesis de estrés ambiental para la diversidad de agallas en la vegetación restinga de las dunas. La Costa Atlántica Restinga es un mosaico de comunidades de plantas con una florística distinta y 
fitofísionomía, expuestas al estrés lumínico, térmico y salino. Las plantas de la restinga deben tener características especiales comúnmente asociadas con ambientes xerófilos, y se espera que alberguen una gran diversidad de herbívoros de agallas. Estudiamos morfotipos de agallas, y registramos la diversidad de agallas en las plantas que crecen en las dunas de arena en un área remanente de restinga (State Park Acaraí) en São Francisco do Sul, estado de Santa Catarina, Brasil. El muestreo se realizó en cuatro parcelas $(250 \times 5 \mathrm{~m})$, lo que constituye una superficie total de $5000 \mathrm{~m}^{2}$, durante abril, mayo y junio. Las ramas de la planta $(n \geq 5)$ con agallas se muestrearon, identificaron y las agallas se fotografiaron. Las agallas se clasificaron en ocho morfotipos, asociados a ocho plantas hospederas que constituyen 15 sistemas planta hospera-herbívoro de agallas. La identificación de los inductores de agallas se basó en la literatura y en la característica específica de la especie de este tipo de interacción planta-inductor de agallas. Hubo un predominio de agallas en las hojas, de color verde. Los morfotipos más comunes fueron: globoides, lenticular, cónico, roseta, marginal y fusiforme, de manera similar a los inventarios realizados en otros biomas brasileños. A pesar de las presiones ambientales, las características xerófitas de las dunas de la ASP, y la alta diversidad de plantas locales, la diversidad de herbívoros de agallas era baja. Varronia curassavica (Boraginaceae), Smilax campestris (Smilacaceae) y Guapira opposita (Nyctaginaceae) fueron super-hospederos de herbívoros de agallas en las dunas, con alrededor del $70 \%$ del total de parásitos asociados. El efecto del ambiente parece ser neutral, ya sea para las plantas hospederas o para la generación de morfotipos de agallas. Por otra parte, los recursos nutricionales escasos podrían ser restrictivos para el establecimiento de los herbívoros parasíticos dentro de los tejidos vegetales.

Palabras clave: dunas, estrés ambiental, interacción insectos-planta, restingas, súper - hospedero.

\section{REFERENCES}

Abrahamsom, W. G., \& Weis, A. E. (1987). Nutritional Ecology of arthropod gall makers. In F. Slansky, \& J. G. Rodriguez (Eds.), Nutritional Ecology of Insects, Mites, Spiders, and Related Invertebrates (pp. 235 258). New York: John Wiley \& Sons.

Araújo, W. S. (2011). Can host plant richness be used as a surrogate for galling insect diversity? Tropical Conservation Science, 4, 420-427.

Araújo, W. S., Scareli-Santos, C., Guilherme, F. A. G., \& Cuevas-Reyes, P. (2013). Comparing galling insect richness among Neotropical savanas: effects of plant richness, vegetation structure and super-host presence. Biodiversity and Conservation, 22, 1083-1094.

Bigarella, J. J. (2001). Contribuição ao estudo da planície litorânea do Estado do Paraná. Brazilian Archives of Biology and Technology (vol. Jubilee): 65-110.
Boeger, M. R. T., \& Gluzezak, R. M. (2006). Adaptações estruturais de sete espécies de plantas para as condições ambientais da área de dunas de Santa Catarina, Brasil. Iheringia Série Botânica, 61(1-2): 73-82.

Bregonci, J. M., Polycarpo, P. V., \& Maia, V. C. (2010). Insect galls of the Parque Estadual Paulo César Vinha (Guarapari, ES, Brazil). Biota Neotropica, 10, 1-11.

Carneiro, M. A. A., Branco, C. S. A., Braga, C. E. D., Almada, E. D., Costa, M. B. M., Maia, V. C., \& Fernandes, G. W. (2009). Are gall midges (Diptera, Cecidomyiidae) host-plant specialists? Revista Brasileira de Zoologia, 53 a, 365-378.

Carneiro, M. A. A., Oliveira, D. C., \& Isaias, R. M. S. (2014). Developmental anatomy and immunocitochemistry reveal the neo-ontogenesis of the leaf tissues of Psidium myrtoides (Myrtaceae) towards the globoid galls of Nothotrioza myrtoids (Tryozoidae). Plant Cell Reports, 33, 2093-2106.

Cordazzo, C. V., Paiva, D. E., \& Seeliger, U. (2006). Guia ilustrado: Plantas de dunas da costa sudoeste Atlântica. Pelotas: USEB.

Dreger-Jauffret, F., \& Shorthouse, J. D. (1992). Diversity of gall-inducing insects and their galls. In J. D. Shorthouse, \& O. Rohfritsch (Eds.), Biology of insectinduced galls (pp. 8-33). Oxford: Oxford University Press.

Espirito-Santo, M. M., \& Fernandes, G. W. (2007). How many species of gall - inducing insects are there on earth, and where are there? Annals of the Entomological Society of America, 100, 95-99.

Evert, R. F. (2013). Anatomia das plantas de Esau. São Paulo: Blucher.

Fatma - Fundação do Meio Ambiente do Estado de Santa Catarina (2008). Plano de manejo do Parque Estadual Acaraí. Plano Básico vol. I/III. (vol. 1). São Francisco do Sul: Santa Catarina.

Fernandes, G. W., \& Price, P. W. (1988). Biogeographical gradients in galling species richness. Test of hypotheses. Oecologia, 7, 161-167.

Fernandes, G. W., \& Price, P. W. (1991). Comparisons of Tropical and Temperate galling species richness: the roles of environmental harshness and plant nutrient status. In P. W. Price, T. M. Lewinsohn, G. W. Fernandes, \& W. W. Beson (Eds.), Plant-animal Interactions Evolutionary Ecology in Tropical and Temperate Regions (pp. 91-115). New York: John Wiley \& Sons.

Fernandes, G. W., \& Price, P. W. (1992). The adaptive significance of insect gall distribution: survivorship of species in xeric and mesic habitats. Oecologia, $76,161-167$.

Ferreira, B. G., \& Isaias, R. M. S. (2013). Developmental stem anatomy and tissue redifferentiation induced by a galling Lepidoptera on Marcetia taxifolia (Melastomataceae). Botany, 91, 752-760. 
Fidalgo, O., \& Bonoini, V. L. R. (1989). Técnicas de coleta, preservação e herborização de material botânico. São Paulo: Instituto de Botânica.

Floate, K. D., Fernandes, G. W., \& Nilsson, J. A. (1996). Distinguishing intrapopulacional categories of plants by their insect faunas: galls on rabbitbrush. Oecologia, 135, 442-50.

Formiga, A. T., Silveira, F. A. O., Fernandes, G. W., \& Isaias, R. M. S. (2014). Phenotypic plasticity and similarity among gall morphotypes on a superhost, Baccharis reticularia (Asteraceae). Plant Biology. doi:10.1111/plb.12232

Gonçalves, S. J. M. R., Isaias, R. M. S., Vale, F. H. A., \& Fernandes, G. W. (2005). Sexual dimorphism of Pseudotectococcus rolliniae Hodgson \& Gonçalves 2004 (Hemiptera Coccoidae Eriococcidae) influences gall morphology on Rollinia laurifolia Schltdl. (Annonaceae). Tropical Zoology, 18, 161-169.

Gonçalves, S. J. M. R., Moreira, G. R. P., \& Isaias, R. M. S. (2009). A unique seasonal cycle in a leaf gall-inducing insect: the formation of stem galls for dormancy. Journal of Natural History, 43, 843-854.

Isaias, R. M. S., Carneiro, R. G. S., Oliveira, D. C., \& Santos, J. C. (2013). Illustrated and Annoted Checklist of Brazilian Gall Morphotypes. Neotropical Entomology, 42, 230-239.

Isaias, R. M. S., Carneiro, R. G. S., Santos, J. C., \& Oliveira, D. C. (2014). Gall morphotypes in the Neotropics and the need to standardize them. In G. W. Fernandes, \& J. C. Santos (Eds.), Neotropical Insect Galls (pp. 51-67). New York: Springer Verlag.

Knie, J. L. W. (Ed.). (2002). Atlas Ambiental da Região de Joinville: Complexo hídrico da Baía da Babitonga. Florianópolis: FATMA/GTZ.

Lista de Espécies da Flora do Brasil. (2014). Jardim Botânico do Rio de Janeiro. Recovered from http:// floradobrasil.jbrj.gov.br/

Magalhães, T. A., Oliveira, D. C., \& Isaias, R. M. S. (2014). Population dynamics of the gall inducer Eriogallococcus isaias (Hemiptera: Coccoidea: Eriococcidae) on Pseudobombax grandiflorum (Malvaceae). Journal of Natural History. 49, 13-14. doi:10.1080/0022 2933.2014.951083

Maia, V. C. (2001). The gall midges (Diptera, Cecidomyiidae) from three restingas of Rio de Janeiro State, Brazil. Revista Brasileira de Zoologia, 18, 583-629.

Maia, V. C. (2011). Characterization of insect galls, gall makers, and associated fauna of Platô Bacaba (Porto de Trombetas, Pará, Brazil). Biota Neotropica, 11(4), 1-18. Recovered from http://www.biotaneotropica. org.br/v11n4/en/abstract?article+bn00511042011

Maia, V. C. (2013). Insect galls from restingas of Southeastern Brazil, with new records. Biota Neotropica, 13, 1-28. doi: 10.1590/S1676-06032013000100021
Maia, V. C., \& Fernandes, G. W. (2004). Insect galls from Serra de São José (Tiradentes, MG, Brazil). Brazilian Journal of Biology, 64, 423-445.

Maia, V. C., \& Oliveira, J. C. (2010). Galhas de insetos da Reserva Biológica Estadual da Praia do Sul (Ilha Grande, Angra dos Reis, RJ). Biota Neotropica, 10, 227-238.

Maia, V. C., \& Souza, M. C. (2013). Insect galls of the xeric vegetation of Ilha do Cabo Frio (Arraial do Cabo, RJ, Brasil). Biota Neotropica, 13 (3), 1-12. Recovered from http://www.biotaneotropica.org.br/v13n3/en/ abstract?inventory+bn02213032013

Maia, V. C., Magenta, M. A. G., \& Martins, S. E. (2008). Occurrence and characterization of insect galls at restinga areas of Bertioga (São Paulo, Brazil). Biota Neotropica, 8: 1-32. Recovered from http://www. biotaneotropica.org.br/v8n1/pt/abstract?inventory+ bn02408012008

Malves, K., \& Frieiro-Costa, F. A. (2012). List of Plants with Galls Induced by Insects from the UNILAVRAS/Boqueirão Biological Reserve, Ingaí, state of Minas Gerais, Brazil. Check List, 8, 426-431.

Melo Jr., J. C. F. (2015). Plasticidade fenotípica e diversidade funcional de comunidades florísticas em gradiente edáfico na restinga do Parque Estadual do Acaraí, São Francisco do Sul/SC (Tese de Doutorado). Universidade Federal do Paraná, Curitiba.

Mendonça Jr., M. S. (2007). Plant diversity and galling arthropod diversity searching for taxonomic patterns in an animal-plant interaction in the neotopics. Boletín de la Sociedad Argentina de Botánica, 42, 347-357.

Mendonça Jr., M. S., Piccardi, H. M. F., Jahnke, S. M., \& Dalbem, R. V. (2010). Galling Arthropod Diversity in Adjacent Swamp Forests and Restinga Vegetation in Rio Grande do Sul, Brazil. Neotropical Entomology, 39, 513-518.

Oliveira, J. C., \& Maia, V. C. (2005). Ocorrência e caracterização de Galhas de insetos na restinga de Grumari (Rio de Janeiro, RJ, Brasil). Arquivos do Museu Nacional, 63, 669-675.

Portugal-Santana, A., \& Isaias, R. M. S. (2014). Galling insects are bioindicators of environmental quality in a Conservation Unit. Acta Botanica Brasilica, 28(4), 594-608.

Raman, A., Schaefer, C. W., \& Withers, T. M. (2005). Biology, Ecology, and Evolution of Gall-inducing Arthropods (Vol. 2). New Hampshire: Science Publishers.

Rodrigues, A. R., Maia, V. C., \& Couri, M. S. (2014). Insect galls of restinga areas of Ilha da Marambaia, Rio de Janeiro, Brazil. Revista Brasileira de Entomologia, 58, 173-197.

Sack, L., Dietrich, E. M., Streeter, C. M., Sánchez-Gómez, D., \& Holbrook, N. M. (2008). Leaf palmate venation 
and vascular redundancy confer tolerancy of hydraulic disruption. Proceedings of the National Academy of Sciences of the United States of America, 105, $1567-1572$

Santos, J. C., Almeida-Cortez, J. S., \& Fernandes, G. W. (2011a). Diversity of gall-inducing insects in the high altitude wetland forests in Pernambuco, Notheastern, Brazil. Brazilian Journal of Biology, 71, 47-56.

Santos, J. C., Almeida-Cortez, J. S., \& Fernandes, G. W. (2011b). Richness of gall-inducing insects in the tropical dry forest (caatinga) of Pernambuco. Revista Brasileira de Entomologia, 55, 45-54.

Santos, J. C., Almeida-Cortez, J. S., \& Fernandes, G. W. (2012). Gall-inducing insects from Atlantic forest of Pernambuco, Northeastern Brazil. Biota Notropica, 12(3), 1-18. Recovered from http://www.biotaneotropica.org.br/v12n3/pt/abstract?inventory+ bn00812032012

Scarano, F. (2002). Structure, Function and Floristic Relationships of Plant communities in Stressful Habitats Marginal to the Brazilian Atlantic Rainforest. Annals of Botany, 90, 517-524.

Shorthouse, J. D., Wool, D., \& Raman, A. (2005). Gallinducing insects - Nature's most sophisticated herbivores. Basic and Applied Ecology, 6, 407-411.

Stone, G. N., \& Schonrogge, K. (2003). The adaptive significance of insect gall morphology. Trends in Ecology and Evolution, 86, 512-522. 